\title{
Ongelmaperustaisesta opetusmenetelmästä laatua yliopistokoulutukseen?
}

\author{
TEEA KANKAANPÄÄ \& HELI I. KOSKINEN
}

\begin{abstract}
Ollakseen laadukkaita yliopistojen olisi kiinnitettävä enemmän huomiota tarjoamaansa opetukseen. Asiasisällön ohella kysymys on myös siitä, millaiset opetusmenetelmät soveltuvat laadukkaan asiantuntijuuden tuottamiseen. Opiskelijat ovat yksilöitä, joilla on omat taipumuksensa ja tavoitteensa. Se haastaa yliopistojen perinteisiä, vahvan luentokeskeisiä opetusmenetelmiä. Kirjoittajat pohtivat sitä, voidaanko ongelmaperustaisella opetusmenetelmällä lisätä yliopisto-opetuksen laadukkuutta ja syventää opiskelijoiden asiantuntijatasoista osaamista.
\end{abstract}

Y liopisto-opetuksen tavoitteena on kehittää opiskelijoiden tieteellistä ajattelua, antaa heille tutkijan valmiuksia sekä tuottaa yhteiskunnan eri tehtäviin henkilöitä, joilla on laaja ja syvällinen asiantuntijuus omalla alallaan. Lisäksi tavoitteena on opiskelijoiden yhteistyö- ja vuorovaikutustaitojen sekä akateemisten keskustelutaitojen kehittyminen. (Nevgi \& Lindblom-Ylänne 2002.) Nevgin ja Lindblom-Ylänteen (2002) mukaan mitään yleistä yliopisto-opetuksen didaktista mallia ei kuitenkaan ole mahdollista kehittää, koska eri tieteenaloilla käytetään hyvin erilaisia opetusmenetelmiä. Nämä eri tieteenalojen opetusmenetelmälliset käytännöt saattavat kuitenkin olla enemmän perinteen sanelemia kuin didaktisesti perusteltuja (Nevgi \& Lindblom-Ylänne 2002; Knubb-Manninen 2004).

Sallisen (1995) mukaan yliopistopedagogiikan kehittämiseen on selkeä tarve, sillä OECD:n asiantuntijaryhmän vuonna 1992 tekemät havainnot kertovat yliopisto-opetuksen ongelmista: opettajilla on heikosti pedagogista koulutusta ja opetustyö ei ole arvostettua, minkä vuoksi opettajat eivät sitoudu opiskelijoiden asiantuntijuuden kehittämiseen. Lisäksi resurssit ovat tiukentuneet niin, että rahoitusta ei tule automaattisesti, vaan se on ansaittava tehokkuudella ja suoritettujen tutkintojen määrällä. Sallinen ehdottaakin konkreettisiksi toimenpiteiksi muun muassa pysyvän arviointijärjestelmän luomista, itsearviointia, yliopistopedagogista koulutusta sekä laa- dukkaita opetushankkeita, jotka olisivat mielellään laitos- ja tiedekuntarajat ylittäviä.

Yliopistojen on tuotettava laatua. Sanakirjamäärityksessä laatu on ominaisuus, jonkin asian korkealuokkaisuus tai erinomaisuus. Harvey ja Green (1993) ovat erotelleet kolme laadun määritelmää korkea-asteen koulutuksen laaduntarkastelussa: 1. Laatu rahan arvossa mitattuna, jolloin tavoitellaan mahdollisimman paljon valmistuvia mahdollisimman vähällä rahalla. 2. Laatu tarkoituksenmukaisuutena, jolloin tarkastellaan, tuottavatko koulutusohjelmat tarkoituksenmukaisia tuloksia. Samalla arvioidaan itse tavoitteiden tärkeyttä. 3. Laatu muuttumisena, jolloin arvioidaan, onko opetus laadultaan sellaista, että se muuttaa opiskelijoiden käsityksiä ja auttaa heitä soveltamaan tietoa. Muuttumisella voidaan myös viitata instituution muuttumiseen tai opettajien käsitysten muuttumiseen.

Laadulla voidaan siis tarkoittaa tehokkuutta joko tuottavuuden tai vaikuttavuuden eli tuloksellisuuden näkökulmasta. Tuottavuudella tarkoitetaan sitä, että tuotettujen hyödykkeiden eli tuotoksen ja tuotantotekijöiden panoksen välinen suhde on tuottajalle edullinen. Vaikuttavuudessa eli tuloksellisuudessa keskeistä on koulutukselle asetettujen tavoitteiden saavuttaminen (Vaherva 1983, 1-6) eli koulutuksen onnistuminen (Raivola ym. 1999, 12). Koulutuksen vaikuttavuus riippuu olennaisesti siitä, kuinka keskeisiä taitoja koulutus 
välittää ja kuinka hyvin välitetyt tiedot ja taidot omaksutaan (Vaherva 1983, 16-20, 37). Myös oppijan oma näkökulma on tärkeää koulutuksen vaikuttavuutta arvioitaessa (Raivola ym. 1999).

\section{Laadukas opetus}

Laadukas opetus on dynaaminen käsite, joka elää ja muuntuu muuttuvien yhteiskunnallisten olosuhteiden ja tieteellisten käsitysten mukaan. Tämän muuntuvuuden vuoksi tarkkojen, pysyvien laadukkuuden kriteerien laatiminen on vaikeaa. (KnubbManninen \& Nuutinen 2002.) Vaikka laadukasta opetusta voidaan luonnehtia sanoilla ”älyllisesti haastavaa", "sosiaalisesti turvallista” ja "emotionaalisesti haastavaa” (Knubb-Manninen 2004), ei ole olemassa yhtä ainoaa hyvää tapaa opettaa. Perinteistä keskittymistä rajatusti valikoitujen hyvätasoisten opiskelijoiden opettamiseen ja uusimman tieteellisen tiedon välittämiseen ei myöskään enää voida pitää riittävinä korkeatasoisen yliopisto-opetuksen kriteereinä (Knubb-Manninen \& Nuutinen 2002).

Entwistlen $(1990,677)$ mukaan laadukas opetus alkaa selvällä esittelyllä opetusjakson tehtävästä ja tavoitteista. Opettajien luentosuunnitelmia analysoitaessa on havaittu, että opettajat usein suunnittelevat luennon sen mukaan, mitä he itse tekevät, ei opiskelijoiden oppimisen tai tekemisen näkökulmasta (Biggs 1990, 681). Opetuksen alkaessa tulisi miettiä, mikä on opiskelijoiden lähtötaso ja minkälaista tiedollista tasoa heiltä odotetaan. Tavallinen ongelma opetuksessa on sisällyttää siihen liikaa asiaa, jolloin syvällinen oppiminen käy mahdottomaksi. (Biggs 2003, 54.)

Opetuksen laadukkuuden voidaan nähdä määräytyvän opetusmenetelmien, oppimisen tavoitteiden ja käytettyjen opiskelumenetelmien tai tapojen linjakkuutena. Linjakkuudella (constructive alignment) tarkoitetaan eräänlaista yhteensopivuutta. Linjakkuudessa esimerkiksi opetusmenetelmä ja oppimisen arviointi määrittyvät opetuksen tavoitteiden mukaan. (Biggs 2003, 11.) Opetuksen tavoitteiden määrittelyssä taas tulisi ottaa opiskelijoiden kyvyt ja tarpeet huomioon. Siksi opetuksen laatua olisi yliopistossa tarkasteltava sekä mikrotasolla yksittäisestä opiskelijasta käsin että makrotasolla koko yliopiston oppimisympäristö huomioon ottaen.

Opetuksen laadukkuuden mittarina voidaan käyttää sen suoraa kytkeytymistä tieteenalan todellisuuteen. Tämä ei ole linjakkuuden vastaista, mikäli tavoitteena on asiantuntijoiden tuottaminen eli laadun tarkastelu vaikuttavuuden näkökulmasta. Esimerkiksi Barnett (1992, 209-210) haluaa nähdä yliopistollisella koulutuksella vahvan käytännöllisen leiman. Hänelle korkea-asteen koulutuksessa edes oppiminen itsessään ei ole keskeisin asia, vaan se, kuinka oppia hyödynnetään. Todisteita koulutuksen laadusta olisikin etsittävä opiskelijoiden koulutuksensa aikana omaksumista työskentely- ja ongelmanratkaisutaidoista (Brown 1999).

Oppimistakin voidaan tarkastella monista näkökulmista. Yksi tavallisimmista on jako syvä- ja pintasuuntautuneeseen lähestymistapaan. Nämä alun perin Martonin ja Säljön (1976) löytämät lähestymistavat kuvaavat erilaisia aikomuksia opiskelun suhteen. Syväsuuntautunut opiskelija pyrkii saavuttamaan syvällisen ymmärryksen ja kokonaiskuvan opittavasta asiasta liittämällä sen aiempiin tietoihinsa ja kokemuksiinsa ja arvioimalla sitä kriittisesti. Pintasuuntautunut opiskelija pyrkii suoriutumaan kurssin vaatimuksista opettelemalla ulkoa erillisiä yksityiskohtia. (Entwistle 1990, 673.) Opiskelija voi myös tavoitella ennen kaikkea hyviä arvosanoja eli ulkoisia palkintoja. Tällainen saavutusmotivaatio (achievement motivation) voi olla yhteydessä sekä pinta- että syväsuuntautuneeseen oppimiseen (Biggs 2003, 62).

Opetus ei kuitenkaan aina johda suoraan oppimiseen. Opetus ja oppimisympäristö voivat parantaa, mutta myös heikentää oppimisen laatua (Barnett 1992, 205). Jotta opetus parantaisi oppimisen laatua, opettajan opetusstrategian ja opiskelijan oppimisstrategian tulisi olla yhteensopivia. Opettajan opetusstrategiat ja opiskelijan oppimisstrategiat voivat poiketa toisistaan esimerkiksi tilanteessa, jossa itsenäiseen, soveltavaan ja pohdiskelevaan otteeseen tottunutta opiskelijaa opetetaan opettajakeskeisesti. (Vermunt \& Verloop 1999.) Uljensin (1997, 37) mukaan opetuksella ei kuitenkaan ole näin suoraa vaikutusta oppimiseen, vaan opetuksen vaikutus välittyy opiskelijoille koko opiskeluprosessin kautta. Biggsin $(2003,56)$ mukaan hyvä opetus kannustaa opiskelijaa paitsi syväsuuntautuneeseen opiskeluun, luo myös hyvää ilmapiiriä ja herättää opiskelijassa motivaatiota opiskeltavaa asiaa kohtaan. Toisaalta hyvä opetus saa opiskelijat myös välttämään pintasuuntautunutta opiskelutapaa ja suosimaan asiantuntijuudelle keskeistä syväsuuntaista lähestymistapaa.

Syväsuuntautuneiden opiskelijoiden onkin 
havaittu ymmärtävän enemmän, saavuttavan parempia oppimistuloksia ja myös muistavan enemmän opeteltavista sisällöistä (Biggs 1987). Tällaisesta oppimisesta on seurannut myös parempi affektiivinen lopputulos kuin pintasuuntautuneesta opiskelusta (Biggs 1990, 691). Laadukkaaksi voitaisiin siis määritellä opetus, jonka suositaan syväsuuntautunutta, ymmärtämään pyrkivää lähestymistapaa. Oppiminen puolestaan muuttuisi laadukkaaksi opiskelijoiden siirryttyä käyttämään syväsuuntautunutta opiskelutapaa. Opiskelijoita voitaisiin siis opetuksellisin menetelmin ohjata syväsuuntautuneiden opiskelutapojen käyttöön. Oppimisen laatua olisi kenties mahdollista parantaa myös erilaisia ja laadukkaiksi havaittuja opetusmenetelmiä monipuolisesti soveltamalla.

\section{Ongelmaperustainen oppiminen}

Ongelmaperustainen oppiminen (problem-based learning, PBL) on ongelmiin ja niiden ratkaisemiseen perustuva ryhmätyöskentelyä hyväksi käyttävä, mutta yksilöllinen opetus-oppimismenetelmä (Koskinen 2005, 13). Barrowsin (1985) mielestä ongelmaperustainen menetelmä sijoittuu helposti nykyisin vallitsevaan konstruktivistiseen, oppijan omaa aktiivisuutta korostavaan viitekehykseen. Tällä menetelmällä toteutettuja opetustilanteita voidaan tarkastella erityisesti pienryhmien ongelmanratkaisuprosesseihin painottuvan sosiaalisen konstruktivismin sekä yhteistoiminnallisen oppimisen näkökulmista (Johnson \& Johnson 2001).

Ongelmaperustaisen oppimisen roolit ovat kognitiivisen psykologian lähtökohdista kahdenlaiset: opetustilanne aidossa työtilanteessa sekä tarjoaa tietoa siinä kontekstissa, jossa sitä myöhemmin tarvitaan että auttaa siirtämään tätä kokemuksellista tietoa oppijan myöhemmin kohtaamiin uusiin ongelmanratkaisutilanteisiin. (Norman \& Schmidt 1992; Egidius 1999a, 7-10.) Juuri tämän vuoksi ongelmaperustaista oppimista pidetään passiiviseen tiedon muistamiseen perustuvan oppimisen jyrkkänä vastakohtana (Barrows 1985, 2, 4).

Kaufman (2000) esittää, että ongelmaperustaisessa oppimisessa voi olla erilaisia muotoja. Opiskelijoita voidaan tukea eri tavalla, arvioida hieman toisistaan poikkeavasti tai ongelmat voidaan esittää eri tavalla. Järjestelmät voivat vaihdella myös oppilaitoksittain (Kaufman 2000; Rothman 2000). Eroista huolimatta ongelmaperustaisella menetelmällä on kuitenkin aina kolme yhteistä piirrettä; ongelmat oppimisen haastajina, tutorit oppimisen tukena sekä ryhmätyöskentely ajatusten jakamisen kanavana (Dolmans ym. 2005). Laadukkaan lopputuloksen kannalta käytännön toteutuksen eroja tärkeämpää on, että teoriaa ja käytäntöä yhdistetään jo opetuksessa sellaisella tavalla, joka aktivoi opiskelijoita ja pitää yllä heidän mielenkiintoaan (Dewey 1980). Tämän vuoksi ongelmaperustaisessa menetelmässä opiskelijat asettavat aluksi itselleen oppimistavoitteet. Kun nämä opiskelijoiden itselleen asettamat oppimistavoitteet nousevat käytännössä havaituista ja kohdatuista ongelmista, opiskeluun myös motivoidutaan uudella tavalla (Hård af Segerstad ym. 1998, 11-12; Harden ym. 2000).

Ongelmaperustaista pedagogiikkaa käytetään laajalti korkeammantasoisessa koulutuksessa (Dolmans ym. 2005), useimmiten lääketieteellisissä koulutusohjelmissa, mutta Poikelan ja Nummenmaan (2002) mukaan myös muissa ammattimaisiin tutkintoihin johtavissa yliopistotasoisissa koulutuksissa, kuten talous- ja kauppatieteissä, agronomikoulutuksessa, insinööritieteissä, oikeustieteessä, opettajankoulutuksessa ja teologiassa. Eläinlääketieteessä ongelmaperustaisuus on kirjattu eläinlääketieteellisen tiedekunnan vuosien 2004-2006 strategiaan. Ongelmaperustaista opetusmenetelmää on edellämainittujen lisäksi sovellettu kulttuurihistorian opetuksessa sekä erilaisissa johtamiskoulutusohjelmissa (Egidius 1999a, 20-23, 45). Ongelmaperustaisen opetusmenetelmän on uskottu edistävän myös ammattikorkeakouluopiskelijoiden asiantuntijavalmiuksien kehittymistä opiskelijoiden itsenäistä ongelmanratkaisukykyä aktivoimalla, minkä vuoksi menetelmää on kokeiltu erityisesti sairaanhoitajaopiskelijoiden opintojaksoilla (Ryan 1993; Andrews \& Jones 1996).

\section{Korkeakoulutuksen ja laadun vaikea yhtälö}

Opetusministeriö on vuodesta 1995 lähtien kiinnittänyt huomiota koulutuksen laatuun ja opetuksen asemaan yliopistoissa. Tämän eräänä seurauksena opetusministeriön alainen Korkeakoulujen arviointineuvosto valitsee hakemuksesta ns. koulutuksen laatuyksiköitä. Valinnan tarkoituksena on korostaa yliopisto-opetuksen, opiskelun ja oppimisen laadun tärkeyttä sekä koulutuksen jatkuvaa kehittämistä. Samalla opetuksen arvioinnin painopistettä pyritään muuttamaan tutkintojen määrän 
laskemisesta kohti laadullisempaa arviointia.

Opetuksen laatuyksikköjen valintakriteerit ovat Knubb-Mannisen ja Nuutisen (2002) mukaan perustuneet paitsi tavoitteiden ja toiminnan välisiin suhteisiin, myös opiskelija- ja työelämänäkökulmien huomioon ottamiseen. Helsingin yliopiston oman opetuksensa laadunarvioinnin tueksi laatima arviointimatriisi perustuu yliopiston strategiaan sekä kansainvälisessä koulutuksen ja tutkintojen arvioinnissa osoitettuihin kehittämiskohteisiin. Tällainen arviointityökalu tukee samalla laitosten kehittävää itsearviointia.

Syvällistä oppimista edistävien opetusmenetelmien käyttö tuntuu painottuvan valintakriteereissä. Esimerkiksi sekä vuosina 1999 että 2004 laatuyksiköksi valittu Helsingin yliopiston lääketieteellinen tiedekunta on toteuttanut vuoden 1993 opintouudistuksestaan lähtien opetuksensa ongelmaperustaista opetusmenetelmää hyödyntäen. Laatuyksikköihin kohdistuvan tutkimuksensa tuloksissa Knubb-Manninen ja Nuutinen (2002) toteavatkin, että opetuksen laadukkuutta tarkastellaan useammin didaktisesti kuin asiantuntijuuden tuottamisen näkökulmasta. Tällöin laadukkaassa opetuksessa korostuvat eniten opetettavan asian hallinta, toimiva vuorovaikutus ja opiskelijoita aktivoivat opetusmenetelmät. Nämäkään eivät ole huonoja laadukkaan opetuksen kriteereitä, mutta eivät välttämättä riittäviä korkeatasoisen asiantuntijuuden kehittämiseen. Laatukriteereinä voitaisiin pitää myös sitä, kuinka opiskelijat osaavat hyödyntää oppimaansa. Toimivaa vuorovaikutusta, aktiivisuutta ja soveltamiskykyä korostava ongelmaperustainen opetusmenetelmä saattaisi siksi olla eräs varteenotettava vaihtoehto laadusta, laadukkaasta opetuksesta ja oppimisesta keskusteltaessa.

Asiantuntijoilla tulee siis olla paitsi tietoa myös kykyä soveltaa tietojaan erilaisten ongelmien ratkaisemiseksi (Barrows 1985, 3; Andrews \& Jones 1996). Mikäli laatu ymmärretään käsitysten muuttumisena ja tiedon soveltamiskykynä Harveyn ja Greenin (1993) laadun kolmannen määritelmän mukaan, tällaista asiantuntijoita tuottavaa yliopistokoulutusta voisi hyvällä syyllä kutsua laadukkaaksi. Tiedon soveltamiskyky edellyttää opetuksen sisältöjen syvällistä ymmärtämistä käytännön elämän yhteyksissään. Se edellyttää myös aktiivista ja kriittistä vaihtoehtojen pohtimista. Koska yliopistojen tehtävänä on tuottaa laajan ja syvällisen tieteellisen ajattelun sisäistäneitä, kriittiseen pohdintaan kykeneviä asiantun- tijoita, tulisi laadulliseksi kutsua opetusmenetelmiä, jotka tukevat näiden ominaisuuksien kehittymistä.

Tästä laadun määritelmän näkökulmasta ongelmaperustaisella opetusmenetelmällä voidaan tuottaa työelämän tarvitsemia, ongelmia syväsuuntautuneesti lähestyviä asiantuntijoita. Tutkimukset lääketieteen opetuksen parissa osoittavat, että ongelmaperustainen oppiminen johdattaa juuri ammatillisen tiedon analysoimiseen ja muokkaamiseen, kriittiseen ajatteluun, käytännön ongelmanratkaisuun ja elinikäiseen oppimiseen (Maudsley \& Strivens 2000) eli tulevaisuuden työelämään (Dolmans ym. 2005) sekä opiskelijoiden itseohjautuvuuteen (Ryan 1993; Van den Hurk ym. 1999; Miflin ym. 2000). Lääketieteen opiskelijat ovat myös itse kokeneet ongelmaperustaiseen opetukseen kuuluneen ammatillisten ongelmien käsittelyn, ryhmänä työskentelyn ja oppimistavoitteiden asettamisen hyvänä tai erittäin hyvänä asiana (Bradley \& Bligh 1999; Crotty ym. 2000; O’Neill ym. 2000).

Ongelmaperustainen opetusmenetelmä jättää kuitenkin opiskelijoiden tietämykseen aukkoja. Sekä Albanese ja Mitchell (1993) että Remmen ym. (1999) ovatkin havainneet tutkimuksissaan, että ongelmaperustaista menetelmää käyttämällä opiskelijat eivät saavuta riittävää opetettavan asian sisällönhallintaa. Tämä vaikuttaa asiantuntijuuden rakenteeseen yksipuolistavasti. Siksi opiskelijoille tarjottavien ongelmien tulee olla laadukkaita ja monipuolisia. Ongelmien tulee sopia opetuksen tavoitteisiin ja opiskelijoiden kykyihin ottamalla opiskelijoiden aikaisemmat tiedot huomioon (Kahney 1986, 20-21; Brown ym. 1997, 145). Ratkaistavaksi tarjottujen tapausten vaikeusasteeseen pitäisi erityisesti kiinnittää huomiota (Gercama ym. 2000; Jacobs ym. 2003; Dolmans ym. 2005; Koskinen 2005). Esimerkiksi osa Kankaanpään (2005) tutkimista Helsingin yliopiston eri tiedekuntien opiskelijoista koki ongelmanratkaisukeskeisessä ympäristössä tarjotut ongelmat vaikeina tai epätarkoituksenmukaisina. Tällaiset opiskelijoiden tasoon nähden liian vaikeat ja epäselvät tehtävät näyttivät erityisesti haittaavan oppimista. Laadukkaan, opetuksen tavoitteiden ja opiskelijoiden tason samanaikaisesti huomioon ottavan oppimateriaalin löytäminen ja valitseminen on kuitenkin monissa oppiaineissa osoittautunut hankalaksi (Egidius 1999b, 75).

Ongelmaperustaisessa menetelmässä työsken- 
nellään vuorotellen sekä ryhmässä että yksin. Yksilöllinen oppiminen eli itsenäinen tiedonhankinta ja yhteinen tiedon konstruointi ovat toisistaan erillisiä prosesseja, joiden yhteisvaikutuksena syvällinen oppiminen käy mahdolliseksi (Poikela \& Nummenmaa 2002, 41). Poikelan ja Nummenmaan $(2002,39)$ mukaan juuri ryhmä on ongelmaperustaisen opiskelun ydin, sillä se tarjoaa heijastuspinnan yksilöllisen oppijan kriittiselle reflektiolle. Yhteisöllisen oppimisen näkökulma onkin korostunut ongelmaperustaisen menetelmän teoriassa ja tutkimuksessa. Jokaisen ryhmän jäsenen oppimiskokemus on kuitenkin henkilökohtainen ja yksilöllinen. Tätä yksilöllisen oppimisen ja jaetun asiantuntijuuden kehittymisen suhdetta ei nykyisissä teoriatarkasteluissa ja tutkimusasetelmissa oteta ollenkaan huomioon.

Ryhmässä työskentely voi vaikuttaa laatuun ja tehokkuuteen kaksijakoisesti. Ryhmä voi saavuttaa yksilöä parempia oppimistuloksia, jos annettu tehtävä koetaan tärkeäksi ja ryhmä merkitykselliseksi. Toimiva ryhmä voi parhaimmillaan tasoittaa yksilö- tai ympäristötekijöihin liittyviä puutteita ja päästä erinomaisiin tuloksiin. Tämä tosin edellyttää, että ryhmässä on samalla opittu myös yliopiston opiskelijoidensa oppimistavoitteeksi asettamia yhteistyö- ja vuorovaikutustaitoja. Pahimmillaan ryhmätyöskentely voi olla ajanhukkaa ja tuloksiltaan mitätöntä, siis heikkolaatuista ja tehotonta. Se voi olla jopa negatiivista (Paganus 2001). Toisaalta minkä tahansa sisällön syväsuuntautunut kognitiivinen prosessointi vaatii pintasuuntautunutta ulkoaoppimista enemmän aikaa. Syvälliseen ymmärtämiseen pyrkivällä pienryhmäperustaisella menetelmällä saavutetut oppimistulokset eivät ole välittömästi havaittavissa ja perinteisin arviointimenetelmin mitattavissa (Albanese 2000). Tämä vaikeuttaa erityisesti opetusmenetelmän lyhyen tähtäimen tehokkuuden arviointia.

Oppimisryhmä muodostuu yksilöistä, joilla on paitsi erilaiset lähtökohdat ryhmätyöskentelyyn, myös erilaiset tavoitteet opiskelua kohtaan yleensä. Slavinin (1991) mukaan sekä ryhmän tavoitteet että ryhmän yksilöiden sitoutuminen ja vastuunotto ovat onnistuneen ryhmätyöskentelyn kannalta keskeisiä tekijöitä. Kankaanpää (2005) on todennut yliopisto-opiskelijoita tutkiessaan, että suurissa opiskelijaryhmissä kaikilla opiskelijoilla ei ole selvää yksilöllistä roolia, mikä voi vähentää sitoutumista yhteiseen tavoitteeseen. Ryhmätyöskentelyyn osallistuminen voi myös olla epätasais- ta sekä toisten opiskelijoiden dominoivan käytöksen että ryhmän tutorin liiallisen keskusteluun puuttumisen seurauksena (Jaques 2000, 24; Paganus 2001; Kankaanpää 2005). Kun siis kritiikinomaisesti viitataan Barrowsin $(1985,2)$ mainitsemaan ongelmaperustaisen opetuksen jäsentymättömyyteen ja tehottomuuteen, viitataan mitä todennäköisimmin nimenomaan ryhmädynaamisiin tekijöihin. Näihin ovat myös Dolmans ym. (2005) kiinnittäneet huomiota ongelmaperustaisen opetusmenetelmän onnistuneisuutta arvioidessaan.

Ryhmätyöskentelyssä onkin monia haasteita, jotka voivat Häkkisen ja Arvajan (1999) mukaan liittyä sekä työnjakoon että ryhmäkeskustelujen syvyyteen. Ryhmän ei esimerkiksi tulisikaan tavoitella jonkin kirjallisen työn (pois)suorittamista tai ongelman ratkaisemista, vaan sen tulisi tavoitella yhdessä oppimista (Slavin 1991). Kankaanpää (2005) on todennut pinnallisen asioiden käsittelyn sekä puutteelliseksi jääneen kokonaisuuksien hahmottamisen heikentäneen opiskelijoiden kokemaa ryhmässä oppimisen laatua. Ryhmäkeskustelujen tulisi olla pohdiskelevia, analysoivia, vertailevia ja yhteistä päätöksentekoa tukevia, ei kiisteleviä tai kritiikittömästi toisten mielipiteitä myötäileviä. Parhaimmillaan ryhmän jäsenet esittävät toisilleen ajatuksia herättäviä kysymyksiä, joihin etsitään yhdessä vastausta. (Häkkinen \& Arvaja 1999.) Tällaisessa ryhmätyöskentelyssä on varmasti jo monia laadukkaan oppimisen piirteitä.

\section{Lähteet}

Albanese, M. (2000). Problem-based learning: why curricula are likely to show little effect on knowledge and clinical skills. Medical Education 34, 729-738.

Albanese, M. \& Mitchell, S. (1993). Problembased learning: a review of literature on its outcomes and implementation issues. Medical Education 34, 729-738.

Andrews, M. \& Jones, P. R. (1996). Problembased learning in an undergraduate nursing programme: a case study. Journal of Advanced Nursing 23, 357-364.

Barrows, H. S. (1985). How to Design a ProblemBased Curriculum for the preclinical Years. New York: Springer, 2-4. 
Barnett, R. (1992). Improving Higher Education. Total Quality Care. USA \& UK: The Society for Research into Higher Education \& Open University Press, 205.

Biggs, J. B. (1987). Student approaches to Learning and Studying. Melbourne: Australian Council for Educational Research, 8-15.

Biggs, J. B (1990). Teaching for Desired Learning Outcomes. Teoksessa Entwistle, N. (toim.), Handbook of Educational Ideas and Practic-es. London and New York: Routledge, 681693.

Biggs, J. B. (2003). Teaching for Quality Learning at University. 2. p. UK \& USA: The Society for Research into Higher Education \& Open University Press, 11, 54, 56, 62.

Bradley, P. \& Bligh, J. (1999). One years‘ experience with a clinical skills resource center. $\mathrm{Me}$ dical Education 33, 114-120.

Brown, G., Bull, G. \& Pendlebury, M. (1997). Assessing Student Learning in Higher Education. London: Routledge, 145.

Brown, S. (1999). Institutional Strategies for Assessment. Teoksessa Brown, S \& Glasner, A. (toim.), Assessment Matters in Higher Education. Choosing and Using Diverse Approaches. Buckingham: The Society for Research into Higher Education \& Open University Press.

Crotty, M., Finucane, P. \& Ahera, M. (2000). Teaching medical students about disability and rehabilitation: methods and student feedback. Medical Education 34, 659-664.

Dewey, J. (1980). Individ, skola och samhälle, pedagogiska texter. Stockholm: Natur och Kultur.

Dolmans, D. H. J. M., De Grave, W., Wolfhagen, I. H. A. P. \& van der Vleuten, C. P. M. (2005). Problem-based learning: future challenges for educational practise and research. Medical Education 39, 732-741

Egidius, H. (1999)a. PBL och casemetodik: hur man gör och varför. Lund: Studentlitteratur, 7-10, 20-23, 45, 55, 57.

Egidius, H. (1999)b. Problembaserat lärandeen introduktion för lärare och lärande. Lund: Studentlitteratur, 75.

Entwistle, N. (1990). Teaching and the Quality of Learning in Higher Education. Teoksessa Entwistle, N. (toim.), Handbook of Educational
Ideas and Practices. London and New York: Routledge, 669-681.

Gercama, A. J., de Haan, M, \& van der Vleuten, C. P. M. (2000). Reliability of the Amsterdam Clinical Challenge Scale (ACCS): a new instrument to assess the level of difficulty of patient cases in medical education. Medical Education 34, 519--524.

Harden, R. M., Crosby, J., \& Davis, M. H. (2000). Task-based learning: the answer to integration and problem-based learning in the clinical years. Medical Education 34, 391-397.

Harvey, L \& Green, D. (1993). Asssessing quality in higher education: A transbinary research project. Assessment and Evalution in Higher Education 18, 143-149.

Hård af Segerstad, H., Helgesson, M., Ringborg, M. \& Svedlin, L. (1998). Problembaserat lärände, Iden, handledaren och gruppen. Falköping: Elanders Gummessons, 11-12.

Häkkinen, P. \& Arvaja, M. (1999). Kollaboratiivinen oppiminen teknologiaympäristöissä. Teoksessa Eteläpelto, A. \& Tynjälä, P. (toim.), Oppiminen ja asiantuntijuus. Työelämän ja koulutuksen näkökulma. Juva: WSOY, 206221.

Jacobs, A. E. J. P., Dolmans, D. H. J. M., Wolfhagen, I. H. A. P., \& Scherpbier, A. J. J. A. (2003). Validation of a short questionnaire to assess the degree of complexity and structuredness of PBL problems. Medical Education 37, 1001-1008.

Jaques, D. (2000). Learning in Groups. A handbook for improving group work. 3. ed. London: Kogan Page, 24.

Johnson, D. W. \& Johnson, R. T. (2001). Yhteistoiminnallinen ongelmanratkaisu. Teoksessa Sahlberg, P \& Shlomo, S. (toim.), Yhteistoiminnallisen oppimisen käsikirja. Helsinki: WSOY, 120-124.

Kahney, H. (1986). Problem Solving: A Cognitive Approach. Philadelphia: Open University Press, 15, 20-21.

Kankaanpää, T. (2005). Tavoiteorientaation yhteys ryhmäoppimiseen yliopisto-opiskelijoilla. Pro gradu- tutkielma. Helsingin yliopisto.

Kaufman, D. M. (2000). Problem-based learningtime to step back? Medical Education 34, 510-511.

Knubb-Manninen, G. (2004). Laadukkaan yliopis- 
to-opetuksen monet kasvot. Peda-Forum 11, 14-15.

Knubb-Manninen, G. \& Nuutinen, A. (2002). Laatuyksikköjärjestelmä oppimisen ja opetuksen kehittämisen välineenä. Muistio korkeakoulujen arviointineuvostolle 20.02.2002.

Koskinen, H. I. (2005). Yliopistotentin murros. SOLO-taksonomia eläinlääketieteellisen lisääntymistieteen oppimistulosten arvioinnissa. Kasvatustieteen laitoksen tutkimuksia 202. Helsinki: Yliopistopaino, 13.

Marton, F. \& Säljö, R. (1976). On qualitative differences in learning 1 - outcome and process. British Journal of Educational Psychology 46, 4-11.

Maudsley, G. \& Strivens, J. (2000). Promoting professional knowledge, experimental learning and critical thinking for medical students. Medical Education 34, 535-544.

Miflin, B. M., Campbell, C. B., \& Price, D. A. (2000). A conceptual framwork to guide the development of self-directed, lifelong learning in problem-based medical curricula. Medical Education 34, 299-306.

Nevgi, A-M. \& Lindblom-Ylänne, S. (2002). Oppimisnäkemykset antavat perustan opetukselle. Teoksessa Lindblom-Ylänne, S. \& Nevgi, A-M. (toim.), Yliopisto- ja korkeakouluopettajan käsikirja. Helsinki: WSOY.

Norman, G. \& Schmidt, H. (1992). The psychological basis of problem-based learning: A review of the evidence. Academic Medicine 67, 557-565.

O’Neill, P. A, Morris, J. \& Baxter, C. M. (2000). Evaluation of an Integrated curriculum using problem-based learning in a clinical environment: the Manchester experience. Medical Education 34, 222-230.

Paganus, N. (2001). Ryhmän toiminta ja ongelmalähtöinen oppiminen kahdessa Helsingin yliopiston lääketieteellisen tiedekunnan pienryhmässä. Pro gradu- tutkielma. Helsingin yliopisto.

Poikela, E. \& Nummenmaa A-R. (2002). Ongelmaperustainen oppiminen tiedon ja osaamisen tuottamisen strategiana. Teoksessa Poikela, E. (toim.), Ongelmaperustainen pedagogiikka. Teoriaa ja käytäntöä. Tampere: Tampere University Press, 33-52.
Raivola, R., Valtonen, P. \& Vuorensyrjä, M. (1999). Käsitteet, mallit ja indikaattorit koulutuksen tehokkuutta ja vaikuttavuutta arvioitaessa. Teoksessa Raivola, R. (toim.), Vaikuttavuutta koulutukseen. Suomen Akatemian koulutuksen vaikuttavuusohjelman tutkimuksia. Suomen Akatemian julkaisuja.

Remmen, R, Derese, A. \& Scherbier, A. (1999). Can medical students rely on clerkships to train students in basic clinical skills? Medical Education 33, 600- 605.

Rothman, A. I. (2000) Problem-based learningtime to move forward? Medical Education 34, 509-510.

Ryan, G. (1993). Student Perceptions about Selfdirected learning in a Professional Course Implementing Problem-based Learning. Studies in Higher Education 18, 53-64.

Sallinen, A. (1995) Opetus ja yliopiston tuloksellisuus. Teoksessa Aaltola, J \& Suortamo, M. (toim.), Yliopisto-opetus. Korkeakoulupedagogiikan haasteita. Opetus 2000 -sarja. Helsinki: WSOY, 10-24.

Slavin, R. E. (1991). Synthesis of Reseach on Cooperative Learning. Educational leadership 48, 71-82.

Uljens, M. (1997). School didactics and learning: a school didactic model framing an analysis of pedagogical implications of learning theory. East Sussex, Great Britain: Psychology Press, 37.

Vaherva, T. (1983). Koulutuksen vaikuttavuus. Käsiteanalyyttistä tarkastelua ja viitekehyksen hahmottelua. Jyväskylän yliopiston kasvatustieteiden laitoksen julkaisuja A1, 1-6, 16-20, 37.

van den Hurk, M. M., Wolfhagen, I. H .A. P. \& Dolmans, D. H. J. M. (1999). The impact of student-generated learning issues on individual study time and academic achievement. Medical Education 33, 808-814.

Vermunt, J. D. \& Verloop, N. (1999). Congruence and Friction between Learning and Teaching. Learning and Instruction 9, 257-280. 